\title{
ANALISIS KUALITAS PELAYANAN KAPAL TELUK SINABANG SEBAGAI JALUR PENGEMBANGAN WISATA BAHARI RUTE LABUHAN HAJI - SIMEULUE
}

\author{
Veranita $^{1}$, Ferdi Saputra ${ }^{2}$ \\ 1), 2) Jurusan Teknik Sipill Universitas Teuku Umar, Jurusan Teknik Sipil \\ Universitas Teuku Umar \\ Email: veranita100281@gmail.com
}

\begin{abstract}
Along with the progress and the growing number users of transport services, companies engaged in the transportation services required to improve the quality of its services, one of which is the perception of the quality service to passengers transport used by consumers. Quality of service is a service of the vessel Kmp.Teluk rated Sinabang these Labuhan HajiSimeulue. The analysis was performed by calculating the Importance Performance Analysis (IPA). The purpose of this research is to identify some of the factors that influence perceptions of service and the level of conformity respondent / passenger sea transportation of Sinabang Kmp.teluk vessel analysis using Perception Index. Analysis of the results of Importance Performance Analysis to come by researchers at the Level of Performance Boats for Suistability Respondent (Tki) 0:09, the assessment Perception by Level of Performance Boats obtained results Suistability Respondent (Tki) 2:33, and the assessment Perception by Importance obtained results Suistability respondents (Tki) 1:00. So the importance of the overall results and performance in getting results overall passenger perception of Conformity Level Respondents $73.94=74($ Tki $74 \%)$. Suistability respondents $(T k i)$ is the result of statements that prove the hypothesis if the value of the average performance of the above as well as the average value of importancelexpectations in the level of suitability of respondents freight ferries KMP.Teluk Sinabang under Tki $<100 \%$, which means transport services KMP.Teluk Sinabang not satisfactory.
\end{abstract}

Keyword : Service, Sea Transportation, Importance Performance Analysis

\section{PENDAHULUAN}

$\mathrm{K}$ abupaten Aceh Selatan, tepatnya di ujung pesisir laut bagian timur beribukota labuhan haji terdapat sebuah pelabuhan yang menghubungkan masyarakat baik dari kota-kota lain untuk menuju kepulauan simeulue. Untuk menuju ketempat tujuan tersebut masyarakat mengunakan sarana angkutan transportasi laut yang berupa kapal penumpang yang biasa disebut juga dengan kapal ferri, dengan biaya yang lumayan murah dengan jarak penyeberangan ditempuh 85 mil laut $(157,42 \mathrm{~km})$. Semakin jauhnya jarak angkutan penyeberangan ini, harus pula diikuti dengan peningkatan kualitas, terutama dari segi keselamatan. Tak terkecuali, didalam pengunaan kapal ferri ini banyak juga yang harus diketahui oleh masyarakat semestinya, diantaranya kelayakan kapal, fasilitas yang belum tertata dan begitu juga dengan faktor- faktor kenyamanan, kesejahteraan penumpang dalam pelayaran menuju tempat tujuan dengan selamat.

Pada kondisi saat ini pelayanan angkutan kapal ferry, memiliki persaingan tarif sehingga menyebabkan beberapa perusahaan menurunkan kualitas pelayanan guna memberikan tarif serendah-rendahnya, ini tentunya sangat berbahaya, terutama jika penurunan kualitas tersebut sudah menyangkut keselamatan penumpang dan umur kapal yang tua masih tetap digunakan. Sebenarnya keselamatan transportasi laut dan peraturan-peraturan tentang keselamatan transportasi laut sudah ada di negara kita, hanya penerapannya yang belum dapat dilaksanakan secara konsekuen. 
Tantangan yang dihadapi adalah armada angkutan laut kedepan dihadapkan dengan peluang yang menantang kinerja pelayanannya, yaitu dengan semakin meningkatnya mobilitas masyarakat sebagai akibat dari peningkatan aktivitas dengan tata guna transportasi yang beragam. Akankah moda transportasi laut (ferri) mampu memberikan kualitas pelayanan yang memadai kepada penggunanya dalam mendukung jalur pengembangan wisata bahari? Untuk mengetahui bagaimana moda transportasi laut dapat meningkatkan kualitas pelayanannya maka diperlukan suatu studi penelitian yang dapat memberikan penjelasan kepada penumpang angkutan tentang pelayanan pada kondisi eksisting dan kualitas pelayanan seperti apa yang harus diberikan pada kondisi yang seperti itu.

Importance-Performance Analysis (IPA) merupakan alat bantu dalam menganalisis atau untuk membandingkan sampai sejauh mana kinerja/pelayanan yang dapat dirasakan oleh pengguna jasa dibandingkan terhadap tingkat kepuasan yang diinginkan. Untuk mengukur tingkat kepentingan dan tingkat kepuasan/kinerja terhadap jawaban responden, digunakan skala lima tingkat. Dari hasil penilaian tingkat kepentingan dan hasil penilaian kinerja, maka akan diperoleh suatu perhitungan mengenai tingkat kesesuaian antara tingkat kepentingan dan tingkat pelaksanaannya.

Tingkat kesesuaian merupakan hasil perbandingan antara skor kinerja pelaksanaan dengan skor kepentingan, sehingga tingkat kesesuaian inilah yang akan menentukan skala perioritas yang akan dipakai dalam penanganan faktor-faktor yang mempengaruhi kepuasan penguna jasa transportasi laut tersebut.

Ada dua buah variabel yang akan menentukan tingkat kinerja penyedia jasa pelayanan (diberi simbol $X$ ) dan tingkat kepentingan pengguna jasa (diberi simbol $Y$ ) sebagaimana dijelaskan pada modul matematika sebagai berikut :

$$
\mathrm{Tki}=\frac{\sum x i}{\sum Y i} \mathrm{x} 100 \%
$$

Dimana :

Tki $=$ Tingkat kesesuaian responden

$\sum x i=$ Skor penilaian kinerja

$\sum Y i=$ Skor harapan responden

Selanjutnya unsur-unsur dari atribut akan dikelompokkan dalam salah satu dari empat kuadran yang disebut dengan diagram kartesius yang dibatasi oleh sumbu $\mathrm{X}$ dan sumbu $\mathrm{Y}$, seperti terlihat dalam Gambar 2.1.

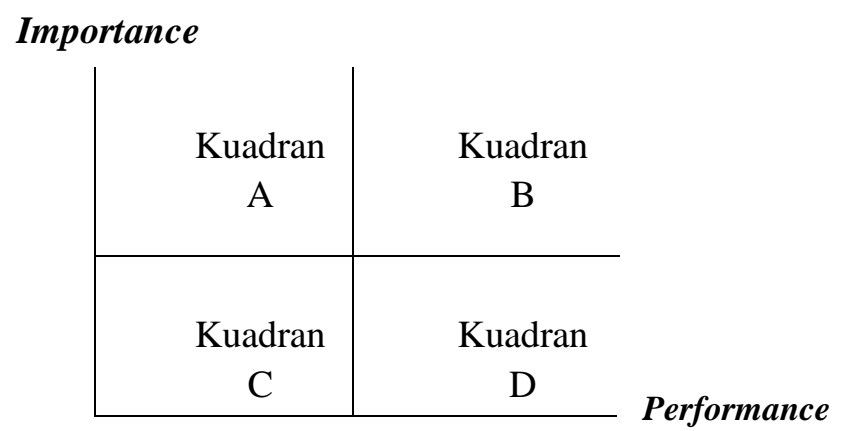

Gambar 2.1 . Importance-Performance Grid Diagram Kartesius

Apabila unsur pelayanan berada pada : 
- $\quad$ kuadran A, maka dapat diartikan juga bahwa menunjukkan Harapan (Importance) terhadap elemen pelayanan yang diberikan pada tingkat yang diinginkan namun Perusahaan belum melaksanakannya sesuai keinginan konsumen sehingga masih perlu diprioritaskan dalam membenahi elemen kualitas pelayanan ini (Prioritas utama).

- Kuadran B, menunjukkan elemen pelayanan yang diberikan telah sangat baik dan perusahaan tersebut harus memelihara kinerja yang telah dicapai (Pertahankan prestasi).

- $\quad$ kuadran $\mathrm{C}$, menunjukkan elemen pelayanan yang masih kurang dan diberikan dengan cara yang sedang saja, tetapi tidak memerlukan perhatian perusahaan, karena dianggap kurang penting oleh konsumen (Prioritas rendah).

- kuadran D, menunjukkan elemen pelayanan yang dianggap kurang penting oleh pelanggan, tetapi sudah diberikan oleh perusahaan dengan sangat baik (Berlebihan).

\section{METODE PENELITIAN}

Untuk mendapatkan hasil suatu perencanaan yang baik maka harus dilakukan metode yang baik. Dalam perencanaan ini metode perencanaan akan dijabarkan dalam setiap langkah-langkah perencanaan.

\subsection{Metode Pengumpulan Data}

Metode pengumpulan data merupakan prosedur yang sistemik dan harus memperhatikan garis yang ditentukan. Hal ini dimaksudkan untuk menghindari data yang tidak terpakai karena informasi yang diperoleh tidak relevan dengan keperluannya. Seluruh data yang diperlukan dalam penelitian ini dapat dikelompokkan menjadi data primer dan data sekunder.

\subsection{Jumlah Sampel}

Jumlah sampel diperoleh dari populasi jumlah rata-rata yaitu 50 orang penumpang angkutan kapal ferri yang dilakukan selama 2 hari dalam 1 (satu) minggu. Menggunakan rumus slovin :

Kapal ferri $=\quad n=\frac{N}{1+N e^{2}}=\frac{280}{1+280.0 .1^{2}}=28$

\subsection{Metode Analisis Data}

Analisis data pada penelitian ini menggunakan analisis hitungan Infortance Performance Analisis (IPA) yang merupakan suatu analisis yang berfungsi untuk menganalisis suatu data dalam nilai indeks kepuasan rata-rata pengguna jasa transportasi laut terhadap factor - faktor pelayanan yang ada pada masyarakat yang menaiki kapal ferri rute labuhan haji - simeulue yang mencangkup berapa persen masuk kriteria cukup puas. Dari analisis inilah akan didapatkan suatu bentuk transportasi yang layak bagi pengunanya dan dapat dilihat pada Halaman 13-14.

1. Identifikasi berbagai faktor yang berpengaruh terhadap perilaku pelaku perjalanan diantaranya:

a) Faktor karakteristik perjalanan (tujuan perjalanan, waktu perjalanan)

b) Faktor karakteristik sistem transportasi (berhubungan dengan kinerja pelayanan sisitem transportasi) seperti kenyamanan, kemudahan pencapaian tempat tujuan dan ketepatan waktu. 
nilai kepuasan pelaku perjalanan yang berhubungan dengan variabel yang memiliki hubungan yang kuat dengan perilaku pelaku perjalanan.

\section{HASIL DAN PEMBAHASAN}

Pada bab ini akan disajikan data dari hasil penelitian sesuai dengan metodelogi yang telah dikemukankan pada bab III,disertai dengan pembahasannya sesuai dengan teori - teori pada bab II.

\subsection{Deskripsi Jawaban Responden}

Deskripsi jawaban responden di sini dimaksudkan untuk menganalisis data berdasarkan hasil yang diperoleh dari jawaban responden terhadap masing masing indikator pengukur variabel. Perhitungan Skor dapat dilihat pada tabel B2, B3, B4 dibawah ini.

Tabel B2 : Tingkat Pelayanan.

(Tanggapan Responden Terhadap Persepsi pelayanan 1)

\begin{tabular}{|c|c|c|c|c|c|c|c|c|c|c|}
\hline \multirow{2}{*}{ NO } & \multirow{2}{*}{ INDIKATOR } & \multicolumn{6}{|c|}{ SKOR } & \multirow{2}{*}{$\mathrm{JMLH}$} & \multirow{2}{*}{ Rata-rata } & \multirow{2}{*}{ Kreteria } \\
\hline & & V & $S$ & B & $\mathrm{N}$ & B & $\mathrm{SB}$ & & & \\
\hline 1 & $\begin{array}{l}\text { Sikap sopan santun petugas ketika melayani } \\
\text { penumpang }\end{array}$ & 0 & 0 & 0 & 0 & 0 & 0 & 0 & 0 & Rendah \\
\hline 2 & $\begin{array}{l}\text { Petugas tidak sopan dan kasar ketika } \\
\text { melayani penumpang }\end{array}$ & 0 & 0 & 0 & 0 & 0 & 0 & 0 & 0 & Rendah \\
\hline 3 & $\begin{array}{l}\text { Petugas sopan tetapi ramah (kasar)ketika } \\
\text { melayani penumpang }\end{array}$ & 0 & 0 & 0 & 0 & 0 & 0 & 0 & 0 & Rendah \\
\hline 4 & Netral & 0 & 0 & 0 & 0 & 0 & 0 & 0 & 0 & Rendah \\
\hline 5 & $\begin{array}{l}\text { Petugas selahu sopan dan ramah ketika } \\
\text { melayani penumpang }\end{array}$ & 0 & 0 & 0 & 0 & 28 & 22 & 50 & 50 & Sangat Tinggi \\
\hline 6 & $\begin{array}{l}\text { Petugas selahu sopan,ramah dan murah } \\
\text { senyum ketika melayani penumpang }\end{array}$ & 0 & 0 & 0 & 0 & 0 & 0 & 0 & 0 & Rendah \\
\hline & Hasil & 0 & 0 & 0 & 0 & 4.67 & 3.67 & & 1.2 & \\
\hline
\end{tabular}

Tabel B2 : Tingkat Pelayanan.

(Tanggapan Responden Terhadap Persepsi pelayanan 2)

\begin{tabular}{|c|c|c|c|c|c|c|c|c|c|}
\hline \multirow{2}{*}{ NO } & \multirow{2}{*}{ INDIKATOR } & \multicolumn{5}{|c|}{ SKOR } & \multirow{2}{*}{ JMLH } & \multirow{2}{*}{ Rata-rata } & \multirow{2}{*}{ Kreteria } \\
\hline & & $\mathrm{TP}$ & $\mathrm{KP}$ & $\mathrm{N}$ & $\mathrm{P}$ & SP & & & \\
\hline 1 & $\begin{array}{l}\text { Sikap sopan santun petugas ketika melayani } \\
\text { penumpang }\end{array}$ & 0 & 0 & 3 & 39 & 11 & 50 & 50 & Sangat Tinggi \\
\hline & Hasil & 0 & 0 & 3 & 39 & 11 & & 3.54 & \\
\hline
\end{tabular}

- Berdasarkan tabel B2 Penilaian Persepsi menurut Tingkat Pelayanan Kapal 1 dan 2 diketahui bahwa hasil penilaian rata-rata (performance) pelayanan kapal KMP.TELUK SINABANG rute labuhan haji-Simeulue adalah $1.27+3.54 / 7=0.69$.

- $\quad$ untuk hasil penilaian rata-rata (inportance) $50 / 7=7.14$ $>$ keterangan Tabel B3 Tingkat Pelayanan Kapal 1 :

$\mathbf{V} \quad=$ VARIABEL

IS S N : $2477-5258$ 


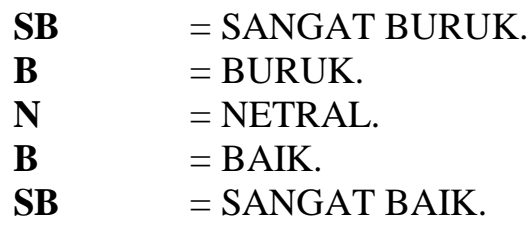

keterangan Tabel B3 Tingkat Pelayanan Kapal 2 :

$\begin{array}{ll}\mathbf{T P} & =\text { TIDAK PENTING. } \\ \mathbf{K P} & =\text { KURANG PENTING. } \\ \mathbf{N} & =\text { NETRAL. } \\ \mathbf{P} & =\text { PENTING. } \\ \mathbf{S P} & =\text { SANGAT PENTING. }\end{array}$

Tabel B3 : Penilaian Persepsi Tingkat Kinerja Kapal. (Skor Tanggapan Responden 1)

\begin{tabular}{|c|c|c|c|c|c|c|c|c|c|}
\hline \multirow{2}{*}{ NO } & \multirow{2}{*}{ INDIKATOR } & \multicolumn{5}{|c|}{ SKOR } & \multirow{2}{*}{ JMLAH } & \multirow{2}{*}{ Rata-rata } & \multirow{2}{*}{ Kreteria } \\
\hline & & SB & B & $\mathrm{CB}$ & B & SB & & & \\
\hline 1 & Sikap ABK dalam melayani penumpang & 0 & 0 & 0 & 0 & 0 & 0 & 0 & Rendah \\
\hline 2 & ABK tidak sopan dan kasar & 0 & 0 & 0 & 0 & 0 & 0 & 0 & Rendah \\
\hline 3 & $\begin{array}{l}\text { Abk marah-marah ketika melayani } \\
\text { penumpang }\end{array}$ & 0 & 0 & 0 & 0 & 0 & 0 & 0 & Rendah \\
\hline 4 & Cukup baik & 0 & 0 & 0 & 0 & 0 & 0 & 0 & Rendah \\
\hline 5 & $\begin{array}{l}\text { ABK selahu ramah ketika melayani } \\
\text { penumpang }\end{array}$ & 0 & 0 & 0 & 37 & 13 & 50 & 50 & Sangat Tinggi \\
\hline 6 & $\begin{array}{l}\text { ABK ramah sopan dan selahu Beredia } \\
\text { membantu }\end{array}$ & 0 & 0 & 0 & 39 & 11 & 50 & 50 & Sangat Tinggi \\
\hline & Hasil & 0 & 0 & 0 & 12.67 & 4.00 & & 3.17 & \\
\hline
\end{tabular}

Tabel B3 : Penilaian Persepsi Tingkat Kinerja Kapal. (Skor Tanggapan Responden 2)

\begin{tabular}{|c|c|c|c|c|c|c|c|c|c|}
\hline \multirow{2}{*}{ NO } & \multirow{2}{*}{ INDIKATOR } & \multicolumn{5}{|c|}{ SKOR } & \multirow{2}{*}{ JULAH } & \multirow{2}{*}{ Rata-rata } & \multirow{2}{*}{ Kreteria } \\
\hline & & SB & B & $\mathrm{CB}$ & B & SB & & & \\
\hline 1 & $\begin{array}{l}\text { Jaminan mendapat mendapat tempat tidur } \\
\text { dikapal }\end{array}$ & 0 & 0 & 0 & 0 & 0 & 0 & 0 & Rendah \\
\hline 2 & $\begin{array}{l}\text { Penumpang tidak mendapat ranjang } \\
\text { padahal mempunyai tiket }\end{array}$ & 0 & 0 & 0 & 0 & 0 & 0 & 0 & Rendah \\
\hline 3 & $\begin{array}{l}\text { Penumpang harus berebut tempat tidur } \\
\text { dengan penumpang lain }\end{array}$ & 0 & 0 & 0 & 0 & 0 & 0 & 0 & Rendah \\
\hline 4 & Cukup baik & 0 & 0 & 0 & 0 & 0 & 0 & 0 & Rendah \\
\hline 5 & $\begin{array}{l}\text { Penumpang tidak perlu berebut tempat } \\
\text { tidur jika telah membeli tiket }\end{array}$ & 0 & 0 & 0 & 37 & 13 & 50 & 50 & Sangat Tinggi \\
\hline 6 & $\begin{array}{l}\text { Penumpang diantar ketempat sesuai } \\
\text { nomor ranjang yang tercantum ditiket }\end{array}$ & 0 & 0 & 0 & 39 & 11 & 0 & 0 & Sangat Tinggi \\
\hline & Hasil & 0 & 0 & 0 & 12.67 & 4.00 & & 3.17 & \\
\hline
\end{tabular}


Tabel B3 : Penilaian Persepsi Tingkat Kinerja Kapal. (Skor Tanggapan Responden 3)

\begin{tabular}{|c|c|c|c|c|c|c|c|c|c|}
\hline \multirow{2}{*}{ NO } & \multirow{2}{*}{ INDIKATOR } & \multicolumn{5}{|c|}{ SKOR } & \multirow{2}{*}{ JMLAH } & \multirow{2}{*}{ Rata-rata } & \multirow{2}{*}{ Kreteria } \\
\hline & & SB & B & $\mathrm{CB}$ & B & SB & & & \\
\hline 1 & Keamanan barang bagasi penumpang & 0 & 0 & 0 & 0 & 0 & 0 & 0 & Rendah \\
\hline 2 & Barang mudah hlang & 0 & 0 & 0 & 0 & 0 & 0 & 0 & Rendah \\
\hline 3 & $\begin{array}{l}\text { Barang mudah tertukar dengan punya } \\
\text { orang lain }\end{array}$ & 0 & 0 & 0 & 0 & 0 & 0 & 0 & Rendah \\
\hline 4 & Cukup baik & 0 & 0 & 0 & 0 & 0 & 0 & 0 & Rendah \\
\hline 5 & Barang tidak mudah hilang & 0 & 0 & 0 & 34 & 16 & 50 & 50 & Sangat Tinggi \\
\hline 6 & $\begin{array}{l}\text { Ada tempat bagasi barang bagi setiap } \\
\text { penumpang dan aman ketempat sesuai } \\
\text { nomor ranjang yang tercantum ditiket }\end{array}$ & 0 & 0 & 0 & 39 & 11 & 50 & 50 & Sangat Tinggi \\
\hline & Hasil & 0 & 0 & 0 & 12.17 & 4.5 & & 2.70 & \\
\hline
\end{tabular}

Tabel B3 : Penilaian Persepsi Tingkat Kinerja Kapal (Skor Tanggapan Responden 4)

\begin{tabular}{|c|c|c|c|c|c|c|c|c|c|}
\hline \multirow{2}{*}{ No } & \multirow{2}{*}{ INDIKATOR } & \multicolumn{5}{|c|}{ SKOR } & \multirow{2}{*}{ ЛМАH } & \multirow{2}{*}{ Rata-rata } & \multirow{2}{*}{ Kreteria } \\
\hline & & SB & B & $C B$ & B & SB & & & \\
\hline 1 & Waktu tba berangkat kapal & 0 & 0 & 0 & 0 & 0 & 0 & 0 & Rendah \\
\hline 2 & Kapal tbba berangkat selahu terlambat & 0 & 0 & 0 & 0 & 0 & 0 & 0 & Rendah \\
\hline 3 & Kapal tibaberangkat sering terlambat & 0 & 0 & 0 & 0 & 0 & 0 & 0 & Rendah \\
\hline 4 & Cukup balk & 0 & 0 & 0 & 0 & 0 & 0 & 0 & Rendah \\
\hline 5 & $\begin{array}{l}\text { Kapal tba berangkat terlambat jijka cuacea } \\
\text { burnk }\end{array}$ & 0 & 0 & 0 & 12 & 38 & 50 & 50 & Sangat Tinggi \\
\hline 6 & Kapal tibal berangkat selatu tepat waktu & 0 & 0 & 0 & 0 & 0 & 0 & 0 & Rendah \\
\hline & Hasil & 0 & 0 & 0 & 2 & 6.33 & & 0.32 & \\
\hline
\end{tabular}

Tabel B3 : Penilaian Persepsi Tingkat Kinerja Kapal. (Skor Tanggapan Responden 5)

\begin{tabular}{|c|c|c|c|c|c|c|c|c|c|}
\hline \multirow{2}{*}{ NO } & \multirow{2}{*}{ INDIKATOR } & \multicolumn{5}{|c|}{ SKOR } & \multirow{2}{*}{ JMLAH } & \multirow{2}{*}{ Rata-rata } & \multirow{2}{*}{ Kreteria } \\
\hline & & SB & B & CB & B & SB & & & \\
\hline 1 & Fasilitas keselamatan dikapal & 0 & 0 & 0 & 0 & 0 & 0 & 0 & Rendah \\
\hline 2 & Tidak tersedia jaket pelampung dikapal & 0 & 0 & 0 & 0 & 0 & 0 & 0 & Rendah \\
\hline 3 & $\begin{array}{l}\text { Tersedia jaket pelampung tetapi tidak } \\
\text { cukup untuk semua }\end{array}$ & 0 & 0 & 0 & 0 & 0 & 0 & 0 & Rendah \\
\hline 4 & Cukup baik & 0 & 0 & 0 & 0 & 0 & 0 & 0 & Rendah \\
\hline 5 & $\begin{array}{l}\text { Tersedia jaket pelampung yang cukup } \\
\text { namun disembunyikan }\end{array}$ & 0 & 0 & 0 & 8 & 42 & 50 & 50 & Sangat Tinggi \\
\hline 6 & $\begin{array}{l}\text { Tersedia jaket pelampung yang cukup } \\
\text { dan mudah diambil ketika keadaan } \\
\text { darurat }\end{array}$ & 0 & 0 & 0 & 0 & 0 & 0 & 0 & Rendah \\
\hline & Hasil & 0 & 0 & 0 & 1.33 & 7 & & 0.19 & \\
\hline
\end{tabular}


Tabel B3 : Penilaian Persepsi Tingkat Kinerja Kapal. (Skor Tanggapan Responden 6)

\begin{tabular}{|c|c|c|c|c|c|c|c|c|c|}
\hline \multirow{2}{*}{ NO } & \multirow{2}{*}{ INDIKATOR } & \multicolumn{5}{|c|}{ SKOR } & \multirow{2}{*}{ ЛMLAH } & \multirow{2}{*}{ Rata-rata } & \multirow{2}{*}{ Kreteria } \\
\hline & & SB & B & $C B$ & B & SB & & & \\
\hline 1 & Fasilitas pendukung dikapal & 0 & 0 & 0 & 0 & 0 & 0 & 0 & Rendah \\
\hline 2 & Hanya ada tempat duduk dituar & 0 & 0 & 0 & 0 & 0 & 0 & 0 & Rendah \\
\hline 3 & Hanya ada dapur dan toilet & 0 & 0 & 0 & 0 & 0 & 0 & 0 & Rendah \\
\hline 4 & Cukup baik & 0 & 0 & 0 & 0 & 0 & 0 & 0 & Rendah \\
\hline 5 & $\begin{array}{l}\text { Ada kantin, dapur, toilet yang bersih,air } \\
\text { bersih yang cukup dan tempat duduk } \\
\text { dithar }\end{array}$ & 0 & 0 & 18 & 21 & 11 & 50 & 50 & Sangat Tinggi \\
\hline 6 & $\begin{array}{l}\text { Ada kantin, music, TV,AC, ruang Medis, } \\
\text { ruang ibadah, jaringan seluler toilet yang } \\
\text { bershh dan cukup air }\end{array}$ & 0 & 0 & 0 & 38 & 12 & 50 & 50 & Sangat Tinggi \\
\hline & Hasil & 0 & 0 & 3 & 9.83 & 3.83 & & 0.08 & \\
\hline
\end{tabular}

Tabel B3 : Penilaian Persepsi Tingkat Kinerja Kapal (Skor Tanggapan Responden 7)

\begin{tabular}{|c|c|c|c|c|c|c|c|c|c|}
\hline \multirow{2}{*}{ No } & \multirow{2}{*}{ INDIKATOR } & \multicolumn{5}{|c|}{ SKOR } & \multirow{2}{*}{ ЛMLAH } & \multirow{2}{*}{ Rata-rata } & \multirow{2}{*}{ Kreteria } \\
\hline & & SB & B & CB & B & SB & & & \\
\hline 1 & Kebershhan dikapal & 0 & 0 & 0 & 0 & 0 & 0 & 0 & Rendah \\
\hline 2 & $\begin{array}{l}\text { Ada genangan air ditoilet dan sampah di } \\
\text { dek kapal }\end{array}$ & 0 & 0 & 0 & 0 & 0 & 0 & 0 & Rendah \\
\hline 3 & $\begin{array}{l}\text { Ada sampah di dek kapal dan ruangan } \\
\text { penumpang ber bau tidak enak }\end{array}$ & 0 & 0 & 0 & 0 & 0 & 0 & 0 & Rendah \\
\hline 4 & Cukup baik & 0 & 0 & 0 & 0 & 0 & 0 & 0 & Rendah \\
\hline 5 & $\begin{array}{l}\text { Tidak ada air tergenang ditoilet WC dan } \\
\text { rangan kapal tidak berbau }\end{array}$ & 4 & 44 & 2 & 0 & 0 & 50 & 50 & Sangat Tingei \\
\hline 6 & $\begin{array}{l}\text { Tidak ada air tergenang } \\
\text { ditoiletWC,dapur bersih dan petugasutin } \\
\text { membersihkan dek kapal }\end{array}$ & 0 & 0 & 0 & 0 & 0 & 0 & 0 & Rendah \\
\hline & Hasil & 0.67 & 7.33 & 0.33 & 0 & 0 & & 0.27 & \\
\hline
\end{tabular}

Tabel B3 : Penilaian Persepsi Tingkat Kinerja Kapal (Skor Tanggapan Responden 8)

\begin{tabular}{|c|c|c|c|c|c|c|c|c|c|}
\hline \multirow{2}{*}{ No } & \multirow{2}{*}{ INDIKATOR } & \multicolumn{5}{|c|}{ SKOR } & \multirow{2}{*}{ JMLAH } & \multirow{2}{*}{ Rata-rata } & \multirow{2}{*}{ Kreteria } \\
\hline & & SB & B & $\mathrm{CB}$ & B & SB & & & \\
\hline 1 & Kenyaman dikapal & 0 & 0 & 0 & 0 & 0 & 0 & 0 & Rendah \\
\hline 2 & $\begin{array}{l}\text { Tidak bisa tidur karena getaran } \\
\text { kapal, berbau dan panas }\end{array}$ & 0 & 0 & 0 & 0 & 0 & 0 & 0 & Rendah \\
\hline 3 & $\begin{array}{l}\text { Mabuk laut karena bau, pengap dan } \\
\text { panas }\end{array}$ & 0 & 0 & 0 & 0 & 0 & 0 & 0 & Rendah \\
\hline 4 & Cukup baik & 0 & 0 & 0 & 0 & 0 & 0 & 0 & Rendah \\
\hline 5 & $\begin{array}{l}\text { Tidak mabuk laut kecuali saat cuaca } \\
\text { burukberombak }\end{array}$ & 0 & 0 & 0 & 0 & 0 & 0 & 0 & Sangat Tinggi \\
\hline 6 & Merasa nyaman dan santai seperti didarat & 0 & 0 & 40 & 10 & 0 & 50 & 50 & Rendah \\
\hline & Hasil & 0 & 0 & 6.67 & 1.67 & 0 & & 4.00 & \\
\hline
\end{tabular}


- Berdasarkan tabel B3 Penilaian Persepsi menurut Tingkat Kinerja Kapal 1,2,3 4,5,6,7,8 diketahui bahwa hasil penilaian rata-rata (performance) pelayanan kapal KMP.TELUK SINABANG rute labuhan haji-Simeulue adalah $100+3.17+3.17+2.70+0.32+0.19+0.8$ $+0.27+4.0 / 6=2.43$.

- $\quad$ untuk hasil penilaian rata-rata (inportance) $50 / 6=1.04$
$>$ keterangan Tabel B3 Penilaian Persepsi menurut Tingkat Kinerja :
SB $=$ SANGAT BURUK.
B $=$ BURUK.
CB = CUKUP BAIK.
B $\quad$ BAIK.
SB $\quad=$ SANGAT BAIK.

Tabel B4 : Penilaian Persepsi Tingkat Kepentingan Untuk Kinerja Kapal (Skor Tanggapan Responden 1)

\begin{tabular}{|c|c|c|c|c|c|c|c|c|c|}
\hline \multirow{2}{*}{ NO } & \multirow{2}{*}{ NDIKATOR } & \multicolumn{5}{|c|}{ SKOR } & \multirow{2}{*}{ JMLAH } & \multirow{2}{*}{ Rata-rata } & \multirow{2}{*}{ Kreteria } \\
\hline & & TP & $\mathrm{KP}$ & $C P$ & $p$ & SP & & & \\
\hline 1 & Sikzap ABK dalam melayani penumpang & 0 & 0 & 0 & 40 & 10 & 50 & 50 & Sangat Tinggi \\
\hline 2 & Jaminan mendapat tempat tidur dikapal & 0 & 0 & 23 & 11 & 16 & 50 & 50 & Sangat Tinggi \\
\hline 3 & Keamanan barang bagasi dipenumpang & 0 & 0 & 1 & 9 & 40 & 50 & 50 & Sangat Tinge \\
\hline 4 & Wakkt tha berangkat kapal & 0 & 0 & 42 & 6 & 2 & 50 & 50 & Sangat Tinggi \\
\hline 5 & Fasilitas keselamatan dikapal & 0 & 0 & 2 & 44 & 4 & 50 & 50 & Sangat Tinggi \\
\hline 6 & Fasilitas pendukung dikapal & 0 & 0 & 40 & 10 & 0 & 50 & 50 & Sangat Tinggi \\
\hline 7 & Kebershhan dikapal & 0 & 0 & 1 & 2 & 47 & 50 & 50 & Sangat Tinggi \\
\hline 8 & Kenyamanan dikkapal & 0 & 0 & 5 & 40 & 5 & 50 & 50 & Sangat Tinggi \\
\hline & Hasil & 0 & 0 & 14.25 & 20.25 & 15.5 & & 0.05 & \\
\hline
\end{tabular}

- $\quad$ Berdasarkan tabel B4 Penilaian Persepsi menurut Tingkat Kepentingan diketahui bahwa hasil penilaian rata-rata (performance) pelayanan kapal KMP.TELUK SINABANG rute labuhan haji - Simeulue adalah $=14.25+20.25+15.5=6.25$.

- untuk hasil penilaian rata-rata (inportance) $50 / 8=6.25$

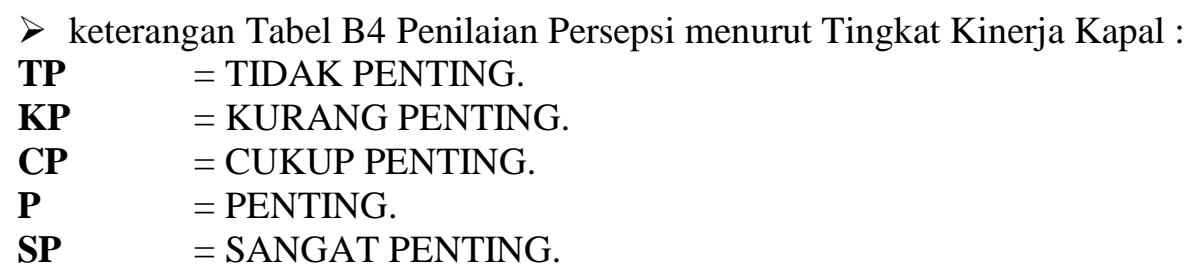

\subsection{Importance-Performance Analysis (IPA).}

Dari hasil diatas maka dilakukan analisa dengan menggunakan rumus-rumus yang dipaparkan pada bab II berdasarkan pengolahan data-data primer maupun sekunder terhadap tingkat perpepsi pelayanan pada kapal ferri KMP.TELUK SINABANG dengan mengunakan Rumus ImportancePerformance Analysis (IPA). 
Berdasarkan hasil perhitungan dengan Important Performance Analysis (IPA) diperoleh nilai rata-rata kinerja (performance),nilai rata-rata harapan (importance), serta nilai rata-rata Performance dan Importance dari setiap variabel kualitas pelayanan dan juga tingkat kesesuaian dari hasil penilaian responden pada Lampiran Tabel B2 Tingkat Pelayanan Kapal, Tabel B3 Penilaian Persepsi menurut Tingkat Kinerja, Tabel B4 Penilaian Persepsi menurut Tingkat Kepentingan Kinerja Kapal diatas maka hasil penilaian importance-performance analysis tiap variabel kualitas pelayanan dan perhitungan tingkat kesesuaian perpepsi pelayanan pada kapal Kmp.teluk sinabang seperti terlihat pada variable dibawah ini :

\begin{tabular}{|c|c|r|r|r|}
\hline No & Variabel & $\begin{array}{r}\text { Rata-rata } \\
\text { Kinerja } \\
(\mathrm{Xi})\end{array}$ & $\begin{array}{r}\text { Rata-rata } \\
\text { Harapan } \\
(\mathrm{Yi})\end{array}$ & $\begin{array}{r}\text { Tingkat } \\
\text { Kesesuaian } \\
(\mathrm{Tki})\end{array}$ \\
\hline 1 & Lampiran Tabel B2 & 0,69 & 7,14 & 0,09 \\
2 & Lampiran Tabel B3 & 2,43 & 1,04 & 2,33 \\
3 & Lampiran Tabel B4 & 6,25 & 6,25 & 1,00 \\
\hline \multicolumn{2}{|c|}{ Rata-rata } & 3,12 & 4,81 & 1,14 \\
\hline
\end{tabular}

Ada dua buah variabel yang akan menentukan tingkat kinerja penyedia jasa pelayanan (diberi simbol $X$ ) dan tingkat kepentingan pengguna jasa (diberi simbol $Y$ ) sebagaimana dijelaskan pada modul matematika sebagai berikut :

$$
\begin{aligned}
1,14 & =\frac{3.12}{4.81} \times 100 \% \\
& =73,94 \\
& =74 \%
\end{aligned}
$$

Selanjutnya unsur-unsur dari atribut akan dikelompokkan dalam salah satu dari empat kuadran yang disebut dengan diagram kartesius yang dibatasi oleh sumbu $\mathrm{X}$ dan sumbu $\mathrm{Y}$, seperti terlihat dalam Gambar 2.1.

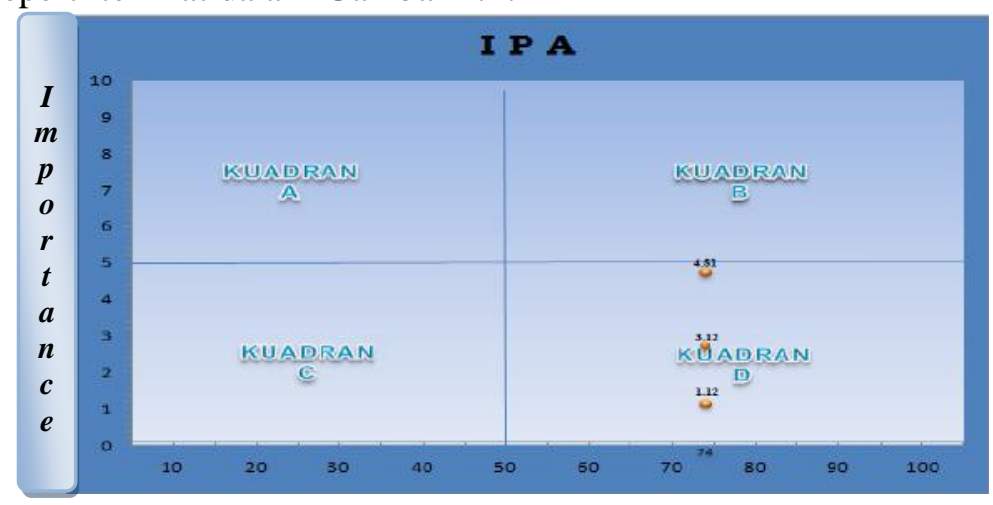

Gambar 2.1 . Importance-Performance Grid Diagram Kartesius

\subsection{Pembahasan}

Berdasarkan hasil penelitian, Dari hasil tabel B3 didapat hasil untuk Tki 0.09, pada tabel B4 didapat hasil Tki 2.33 dan pada tabel B5 didapat hasil Tki 1.00. Sehingga dari hasil keseluruhan importance dan performance tabel B2,B3,dan B4 di dapatkan hasil persepsi penumpang keseluruhan dari Tingkat Kesesuaian Responden (Tki 74\%). 
Tingkat Kesesuaian Responden (Tki) adalah hasil Pernyataan hipotesis yang membuktikan apabila nilai rata-rata performance/kinerja diatas serta nilai rata-rata importance/harapan dalam tingkat kesesuaian responden angkutan kapal ferri KMP.Teluk Sinabang dibawah Tki<100\%, Yang berarti pelayanan angkutan kapal ferri KMP. Teluk Sinabang belum memuaskan.

Variabel yang menentukan tingkat kinerja penyedia jasa pelayanan $(X)$ dan tingkat kepentingan pengguna jasa $(Y)$ sebagaimana dijelaskan pada modul matematika diatas didapat tingkat kesesuaian perpepsi pelayanan pada kapal KMP.TELUK SINABANG $=74 \%$.

Dari hasil Importance-Performance Grid Diagram Kartesius yang terlihat diatas unsur pelayanan yang menepati kuadran $\mathrm{D}$, menunjukkan elemen pelayanan yang dianggap kurang penting oleh pelanggan, tetapi sudah diberikan oleh perusahaan dengan sangat baik (Berlebihan).

\section{KESIMPULAN}

Berdasarkan hasil penelitian yang telah dilakukan terhadap karakteristik campuran aspal porus, maka dapat disimpulkan :

1. Berdasarkan dari perhitungan dengan Importance-Performance Analysis sebagai Instrumen Penilaian Kualitas persepsi pelayanan diperoleh hasil persepsi pelayanan dalam kapal angkutan kapal ferri KMP.TELUK SINABANG rute labuhan haji-simeulue yang digerakkan oleh Dinas PT. ASDP pada sarana transportasi angkutan penumpang kapal ferri KMP.TELUK SINABANG belum memuaskan,dengan harapan agar dapat kiranya meningkatkan pelayanan fasilitas yang lebih baik lagi kedepan bagi semua terutama untuk penumpang kapal.

2. Variabel Deskripsi kinerjanya memiliki nilai terendah berdasarkan respon dari responden/penumpang, dimana terlihat posisinya di kuadran D pada Diagram kartesius, yang berarti menunjukkan elemen pelayanan yang masih kurang dan diberikan dengan cara yang sedang saja, tetapi tidak memerlukan perhatian perusahaan, karena dianggap kurang penting oleh konsumen.

3. Prioritas dari kuadran yang disurvei selama 2 hari dalam seminggu di tempat penelitian ini didapat hasil bahwa prioritas dari kuadran $\mathrm{D}$ yang didapatkan adalah prioritas rendah, dengan demikian prioritas untuk pihak PT.ASDP dan Kapal KMP.TELUK SINABANG harus lebih dioptimalkan untuk kedepan.

\section{SARAN}

Setelah memperoleh kesimpulan dari hasil penelitian, selanjutnya dapat diberikan rekomendasi atau saran terutama kepada KMP. TELUK SINABANG rute labuhan haji-simeulue yang digerakkan oleh Dinas PT.ASDP untuk dapat kiranya memperhatikan tingkat persepsi pelayanan dan tingkat kepentingan untuk kinerja kapal (nahkoda dan anak buah kapal(ABK). Oleh karena kurangnya perhatian dari pihak Dinas PT.ASDP yang sekarang ini belum sesuai dengan harapan yang diinginkan penumpang kapal,serta fasilitas kapal yang belum memadai.

\section{DAFTAR PUSTAKA}

[1] Andi Wahyu,H.,(2008), Analisis Tingkat Kepuasan Konsumen Terhadap Pelayanan Terminal Peti Kemas di Pelabuhan Semarang.

[2] Ibrahim,B.,(1997) Total Quality Manajemen, Panduan untuk menghadapi Persaingan Global, Penerbit DJambatan,Jakarta.

[3] Jinca,M.Y.,2011,Transportasi Laut Indonesia,Brilian Internasional, Surabaya.

[4] Kotler,P.,1995, Manajemen Pemasaran Analysis Perencanaan dan Imple mentasi, Salemba 
Empat, Jakarta.

[5] Khisty C. J.,Lall B.K.,2005, Dasar-Dasar Rekayasa Tranportasi, Penerbit Erlangga Jakarta.

[6] Lovelock,C.H., dan Wright.L.K.,2007, Manajemen Pemasaran Jasa : Alih bahasa Agus Widyantoro, PT. INDEKS Jakarta

[7] Manheim,L.,M.,1979, Fundamental Transportation Systems Analysis, Volume I, Basic Concept, The MIT Press, Cambridge.

[8] Martila A. John and James C. John,1997, "The Analysis of the Importance and Satisfaction level of the Customers" Prentice Hall Inc.

[9]Miro.,2005., Populasi sampel pada kepuasan pengguna transportasi laut.

[10] M.Yamin Jinca.,2010, Jaringan Pelayanan Angkutan Laut Perintis di Kawasan Timur Indonesia.

[11] Poerwadarminta,W.J.S.,2001, Kamus Umum Bahasa Indonesia, Balai Pustaka, Jakarta

[12] Singarimbun, M.,dan Effendi,S.,1995, Metode Penelitian Survei, Edisi Kedua, LP3ES, Jakarta.

[13] Sinulingga.,2005, Transportasi yang dikatakan baik serta mendapatkan pelayanan yang sesuai keinginan

[14] Sri Pramono,S.,2005, Faktor-Faktor yang Mempengaruhi Pilihan Konsumen pada Jenis Kapal Angkutan Laut Semarang - Pontianak, Tesis.

[15] Sujarweni,V.W.,2007, SPSS untuk Penelitian, Global Media Informasi, Yogjakarta.

[16] Sedarmayanti,2011, Metodologi Penelitian, CV. Mandar Maju, Bandung.

[17] Tjiptono,F.,1995, Manajemen Jasa, Penerbit Andi,Yogyakarta.

[18] Zeithaml,A.,V.,Parasuraman, A., and Berry, L., L., 1990, Delivering Quality, Service Balancing Customer Perception and Expectation, The Press New York. 